\title{
Hypertensjon hos friske over 80 år bør behandles
}

\author{
Hvordan skal man forholde seg til medikamentell blodtrykksbehandling når pasienten er over 80 år? \\ Siden det blir stadig flere og friskere eldre og blodtrykket øker med alderen, er problemstillingen ikke \\ uvanlig. Er pasienten en frisk 80 -åring, mener vi behandling av hypertensjon vil være gunstig.
}

$31 \%$ av alle dødsfall i Norge i 2011 skyldtes kardiovaskulær sykdom, som dermed er den ledende dødsårsaken (1). Hypertensjon er en viktig risikofaktor for kardiovaskulær sykdom. Det systoliske blodtrykket øker med alderen, det diastoliske stiger først for deretter å synke fra ca. 60 års alder (2). Derfor er det nærmest unormalt ikke å være hypertensiv når man når en viss alder. Befolkningsandelen av dem over 80 år er forventet å øke til $7 \%$ i 2040 , fra ca. $4 \%$ i dag (3).

Sammenhengen mellom hypertensjon og kardiovaskulær sykdom samt nytteverdien av medikamentell behandling er meget godt etablert når det gjelder dem over 65 år. Hvorvidt behandling er positivt for pasienter over 80 år, har lenge vært et ubesvart spørsmål. Behandling for denne aldersgruppen er etisk og økonomisk utfordrende (4). Derfor er det viktig med et solid fundament når avgjørelsen skal tas.

\section{Forskning på veldig gamle og hypertensjon}

I INDANA-gruppens metaanalyse (5) fra 1999 var 1670 veldig gamle, definert som $\geq 80$ år, fra sju primærstudier inkludert. Man fant en statistisk signifikant redusert risiko for slag med og uten dødelig utfall og en ikke-signifikant, men urovekkende, relativ risikoøkning for død på $6 \%$ hos veldig gamle som ble behandlet for hypertensjon.

Etter dette kom studien HYpertension in the Very Elderly Trial (HYVET) (6). Basert på lang erfaring i fagområdet kan denne trygt sies å være den til nå eneste gode primærstudien av veldig gamle som har tilstrekkelig statistisk styrke, og den vil sannsynligvis være det $\mathrm{i}$ lang tid. HYVET-studien inkluderte 3845 pasienter fra bl.a. ØstEuropa (56\%), Kina (40\%) og Vest-Europa $(2,2 \%)$. Gjennomsnittsalderen var 83,6 år og median oppfølgingstid 1,8 år. Pasientene hadde sittende systolisk blodtrykk på 160-199 mm Hg og stående blodtrykk over $140 \mathrm{~mm} \mathrm{Hg}$. Isolert systolisk hypertensjon ble også inkludert. Pasientene ble randomisert til placebobehandling eller behandling med et tiaziddiuretikum, eventuelt med tillegg av ACE-hemmer.

I HYVET-studien ville man minimere frafallet underveis og stilte derfor strenge helsekrav. Pasienter med bl.a. akselerert hypertensjon, ortostatisk hypotensjon, åpenbart behandlingstrengende hjertesvikt, nyresvikt (serum-kreatininnivå > $150 \mu \mathrm{mol} /$ 1), tidligere hjerneblødning, kort forventet levetid, sekundær hypertensjon, urinsyregikt, demens og stort pleiebehov og de som var sengebundet ble ekskludert. Gjennomsnittsdeltakeren i studien hadde kroppsmasseindeks $25 \mathrm{~kg} / \mathrm{m}^{2}$, hvilepuls $75 / \mathrm{min}$,

\section{«Dersom vi behandler sju hypertensive 80-åringer i resten av deres liv, kan vi potensielt forebygge én alvorlig kardio- vaskulær hendelse»}

totalkolesterolnivå 5,3 mmol/1 og HDLkolesterolnivå $1,35 \mathrm{mmol} / \mathrm{l}$. Det var $60 \%$ kvinner, 6,5\% aktive røykere og 6,8\% diabetikere, og $8,4 \%$ hadde ortostatisk hypotensjon. Ortostatisme er så vanlig hos eldre at selv om dette var eksklusjonsgrunn ved randomiseringen, oppdaget man deltakere med ortostatisk hypotensjon senere i forløpet.

\section{Redusert risiko for død}

Omtrent halvparten av dem som fikk aktiv behandling, nådde behandlingsmålet på under $150 \mathrm{~mm} \mathrm{Hg}$ systolisk og $80 \mathrm{~mm} \mathrm{Hg}$ diastolisk sittende blodtrykk. I begge randomiseringsgruppene var gjennomsnittlig reduksjon av sittende og stående blodtrykk omtrent like stor, noe som kan tyde på at ortostatisk hypotensjon ikke økte som en følge av behandlingen. Placebogruppen oppnådde i gjennomsnitt omtrent halvparten av blodtrykksreduksjonen som i den aktive gruppen.

De viktigste resultatene fra HYVET-studien er en statistisk signifikant reduksjon i relativ risiko for død av alle årsaker på $21 \%$ i behandlingsgruppen, noe som avkrefter tidligere indikasjoner om økt dødelighet. Dette resultatet viste seg ved andre interimsanalyse og gjorde at studien ble avsluttet av etiske årsaker. Likevel skal man ikke kategorisk utelukke at INDANA- gruppen observerte en reell skadelig effekt, siden deres studiepopulasjon ikke var like frisk som den i HYVET-studien.

Andre signifikante resultater er reduksjon av relativ risiko for dødelig hjerneslag (39\%), hjertesvikt (64\%) og kardiovaskulære hendelser (34\%). En kardiovaskulær hendelse inkluderte hjerteinfarkt, hjertesvikt eller død av kardiovaskulær årsak eller slag. Ingen studier har kunnet vise signifikant reduksjon av død med kardiovaskulær årsak, men HYVET-studien indikerer at dette er tilfellet. Mangelen på flere signifikante resultater må ses i lys av den tidlige avslutningen og at studiepopulasjonen var relativt frisk.

\section{Uønskede bivirkninger}

Medikamentene brukt i HYVET-studien ga kun små endringer i serumverdiene av kalium, urinsyre, glukose og kreatinin. I gruppen som fikk aktiv behandling rapporterte $18,5 \%$ om alvorlige uønskede bivirkninger, mot $23,4 \%$ i kontrollgruppen. Bare fem av hendelsene ble vurdert å være en mulig effekt av studiemedikamentene.

Den svenske studien STOP-2 (7), der man sammenliknet effekten av ulike medikamentelle behandlingsalternativer (betablokker og tiaziddiuretika, ACE-hemmer eller kalsiumantagonist) mot hypertensjon, inkluderte 6600 eldre opptil 84 år, med gjennomsnittsalder 75 år. Denne studien ga mer konkret informasjon om bivirkninger. Spesielt hyppige var tørrhoste, svimmelhet, ankelødem, tungpustethet og hodepine. Tørrhoste var karakteristisk for behandling med ACE-hemmer og hodepine og ankelødem for behandling med kalsiumantagonist, mens alle medikamentene hadde svimmelhet som bivirkning.

\section{Start behandling i tide}

I oppfølgingsstudien til HYVET (8) ble pasienter fra hovedstudien invitert til ett års oppfølging der alle fikk aktiv behandling. Effekten av ulik behandlingslengde ble studert ved å sammenlikne den opprinnelige placebogruppen (kort behandlingstid) med gruppen som hadde fått aktiv behandling tidligere (lang behandlingstid). Deltakelsen var frivillig, og den mulige skjevheten i hvem som valgte å delta er derfor en svakhet.

Allerede etter seks måneder var det ingen signifikant forskjell i blodtrykk mellom gruppene, og etter ett år var det ingen for- 
skjell i risiko for slag og hjertesvikt. Relativ risiko for død av kardiovaskulær årsak, og totaldødeligheten, var signifikant større hos den opprinnelige placebogruppen, henholdsvis $52 \%$ og $81 \%$. Dette understreker viktigheten av å starte behandling tidlig for å oppnå full fordel. Siden behandlingen er godt tolerert og livsforlengende, og prevalensen av hypertensjon er meget høy, taler det for at man regelmessig bør måle blodtrykket for å oppdage og behandle hypertensjon også hos veldig gamle.

\section{Overføringsverdi til klinisk praksis}

Den største begrensningen ved HYVETstudien ligger $i$ at deltakerne hadde god helse i utgangspunktet. Om den positive effekten gjelder for skrøpelige og syke 80åringer, er fortsatt usikkert. Den andre viktige begrensningen er at $96 \%$ av deltakerne var fra Øst-Europa og Kina, noe som er en kilde til kulturell og genetisk forskjell fra en norsk pasient.

\section{Tallenes tale}

Medikamentell behandling av hypertensjon hos veldig gamle gir redusert kardiovaskulær sykelighet og færre dødsfall totalt. Med utgangspunkt i resultatene fra HYVET-studien finner man at ett års behandling av 81 pasienter kan forhindre ett dødsfall. For slag er tallet 188 , for død av kardiovaskulær årsak 147 og for hjertesvikt 105 . Sett under ett må man behandle 59 pasienter i ett år for å unngå ett slag, hjerteinfarkt, tilfelle av hjertesvikt eller annen kardiovaskulær hendelse med eller uten dødelig utfall.

I dag har en 80-åring i gjennomsnitt ni år igjen å leve (3). Basert på HYVET-studien kan vi lage følgende illustrasjon (selv om studien måtte avsluttes tidlig av etiske hensyn og man derfor ikke fikk studert langtidseffekter): Dersom vi behandler sju hypertensive 80 -åringer i resten av deres liv, kan vi potensielt forebygge én alvorlig kardiovaskulær hendelse.
Etter gjeldende norske retningslinjer (9) anbefales det at blodtrykksbehandling skal vurderes individuelt ved alder over 70 år. Utover dette er det få konkrete anbefalinger som gjelder hypertensive eldre over 80 år, og verktøyene for å beregne risiko begrenser seg oppad til 70 år.

Vi mener behovet for blodtrykksbehandling bør vurderes hos alle over 80 år. Hos friske pasienter uten ortostatisme bør behandling startes dersom systolisk trykk er $\geq 160 \mathrm{~mm} \mathrm{Hg}$, med behandlingsmål $<150 \mathrm{~mm} \mathrm{Hg}$. Dette er i tråd med retningslinjer fra National Institute for Health and Clinical Excellence (10) og amerikanske retningslinjer (11). I vurderingen må det tas hensyn til individuelle faktorer og pasientens ønsker. Polyfarmasi er vanlig hos geriatriske pasienter, og en løpende vurdering av medikamentenes nytteverdi og den enkelte pasients evne til etterlevelse er spesielt viktig.

Artikkelen er basert på en studentoppgave ved Det medisinske fakultet, Universitetet i Oslo.

\section{Kristian Vinkenes}

Sverre Erik Kjeldsen

s.e.kjeldsen@medisin.uio.no

Kristian Vinkenes (f. 1980) er medisinstudent ved Universitetet i Oslo.

Forfatter har fylt ut ICMJE-skjemaet og oppgir ingen interessekonflikter.

Sverre Erik Kjeldsen (f. 1953) er indremedisiner og kardiolog. Han er professor og seksjonsoverlege ved Hjertemedisinsk avdeling, Oslo universitetssykehus, Ullevål.

Forfatter har fylt ut ICMJE-skjemaet og oppgir følgende interessekonflikter: Han har mottatt konsultasjonshonorar/forskningsstøtte/foredragshonorar fra Bayer, Medtronic, Serodus, Takeda, AstraZeneca, Pronova, MSD.
Litteratur

1. Nasjonalt folkehelseinstitutt. Dødsårsaksregisteret. www.norgeshelsa.no/norgeshelsa (28.2.2013).

2. Franklin SS, Gustin W 4th, Wong ND et al. Hemodynamic patterns of age-related changes in blood pressure. The Framingham Heart Study. Circulation 1997; 96: 308-15.

3. Statistisk sentralbyrå. Befolkningsframskrivinger. www.ssb.no/befolkning (28.2.2013)

4. Petursson H, Getz L, Sigurdsson JA et al. Current European guidelines for management of arterial hypertension: are they adequate for use in primary care? Modelling study based on the Norwegian HUNT 2 population. BMC Fam Pract 2009: 10: 70.

5. Gueyffier F, Bulpitt C, Boissel JP et al. Antihypertensive drugs in very old people: a subgroup metaanalysis of randomised controlled trials. Lancet 1999: 353: 793-6.

6. Beckett NS, Peters R, Fletcher AE et al. Treatment of hypertension in patients 80 years of age or older. N Engl J Med 2008; 358: 1887-98.

7. Hansson L, Lindholm LH, Ekbom T et al. Randomised trial of old and new antihypertensive drugs in elderly patients: cardiovascular mortality and morbidity the Swedish Trial in Old Patients with Hypertension-2 study. Lancet 1999; 354: 1751-6.

8. Beckett N, Peters R, Tuomilehto J et al. Immediate and late benefits of treating very elderly people with hypertension: results from active treatment extension to Hypertension in the Very Elderly randomised controlled trial. BMJ 2012; 344: d7541.

9. Nasjonal faglig retningslinje for individuell primærforebygging av hjerte- og karsykdommer. IS-1550. Oslo: Helsedirektoratet, 2009.

10. Hypertension: Clinical management of primary hypertension in adults. CG127. London: National Institute for Health and Clinical Excellence, 2011.

11. Aronow WS, Fleg JL, Pepine CJ et al. ACCF/AHA 2011 expert consensus document on hypertension in the elderly: a report of the American College of Cardiology Foundation Task Force on Clinical Expert Consensus Documents. Circulation 2011 : 123: $2434-506$

Mottatt 17.4. 2013, første revisjon innsendt 7.6. 2013, godkjent 1.7. 2013. Medisinsk redaktør Hanne Støre Valeur.

> Se også side 1792

Publisert først på nett. 